\title{
Environmental and Agronomic Implications of Water Table and Nitrogen Fertilization Management
}

\author{
Abdirashid A. Elmi, Chandra Madramootoo, Mohamud Egeh, Aiguo Liu, and Chantal Hamel*
}

\begin{abstract}
Nitrate $\left(\mathrm{NO}_{3}^{-}\right)$pollution of surface and subsurface waters has become a major problem in agricultural ecosystems. Field trials were conducted from 1996 to 1998 at St-Emmanuel, Quebec, Canada, to investigate the combined effects of water table management (WTM) and nitrogen $(\mathrm{N})$ fertilization on soil $\mathrm{NO}_{3}^{-}$level, denitrification rate, and corn (Zea mays L.) grain yield. Treatments consisted of a combination of two water table treatments: free drainage (FD) with open drains at a 1.0-m depth from the soil surface and subirrigation (SI) with a design water table of $0.6 \mathrm{~m}$ below the soil surface, and two $\mathrm{N}$ fertilizer (ammonium nitrate) rates: $120 \mathrm{~kg} \mathrm{~N} \mathrm{ha}^{-1}\left(\mathrm{~N}_{120}\right)$ and $200 \mathrm{~kg}$ $\mathbf{N ~ h a}^{-1}\left(\mathbf{N}_{200}\right)$. Compared with FD, SI reduced $\mathrm{NO}_{3}^{-}-\mathbf{N}$ concentrations in the soil profile by $37 \%$ in spring 1997 and $2 \%$ in spring 1998; and by $45 \%$ in fall 1997 and $19 \%$ in fall $1998\left(1 \mathrm{mg} \mathrm{NO}_{3}^{-}-\mathrm{N} \mathrm{L}^{-1}\right.$ equals approximately $4.43 \mathrm{mg} \mathrm{NO}_{3}^{-} \mathrm{L}^{-1}$ ). The higher rate of $\mathrm{N}$ fertilization resulted in greater levels of $\mathrm{NO}_{3}^{-}-\mathrm{N}$ in the soil solution. Denitrification rates were higher in SI than in FD plots, but were unaffected by $\mathbf{N}$ rate. The $N_{200}$ rate produced higher yields than $N_{120}$ in 1996 and 1997, but not 1998. Corn yields in SI plots were 7\% higher than FD plots in 1996 and 3\% higher in 1997, but 25\% lower in 1998 because the SI system was unable to drain the unusually heavy June rains, resulting in waterlogging. These findings suggest that SI can be used as an economical means of reducing $\mathrm{NO}_{3}^{-}$pollution without compromising crop yields during normal growing seasons.
\end{abstract}

$\mathrm{N}^{\prime}$ TRATE $\left(\mathrm{NO}_{3}^{-}\right)$pollution of both surface and ground water has become a widely recognized risk in intensively managed agricultural ecosystems. Agricultural activities are considered to be among the most significant sources of $\mathrm{NO}_{3}^{-}$contamination. Intensive use of nitrogen fertilizer to aid food production may lead to increased $\mathrm{NO}_{3}^{-}$levels in surface water bodies, promoting eutrophication of surface waters by stimulating algae growth (Yeomans et al., 1992). Furthermore, $\mathrm{NO}_{3}^{-}$leaching represents a potential source for the degradation of ground water quality (Prunty and Montgomery, 1991). Human consumption of water containing high $\mathrm{NO}_{3}^{-}$concentrations has been linked to cases of methemoglobinemia, also known as blue baby syndrome, which in extreme cases can result in the death of infants of 4 to 6 mo (Comly, 1945; Gelberg et al., 1999), and can cause other health disorders (Prasad and Power, 1995).

Prevention is preferable to the restoration of polluted aquifers. Nonetheless, in some situations it is already too late for prevention, and costly treatments may become inevitable before water is fit for human consumption or recreational purposes. In many regions of the United States, wells have exhibited $\mathrm{NO}_{3}^{-}$concentrations exceed-

A.A. Elmi, A. Liu, and C. Hamel, Dep. of Natural Resource Science, and C. Madramootoo and M. Egeh, Dep. of Agric. Biosyst. Engineering, Macdonald Campus of McGill University, 21111 Lakeshore Rd. Ste-Anne-de-Bellevue, QC, Canada H9X 3V9. Received 28 Sept. 2001. *Corresponding author (Hamel@nrs.mcgill.ca).

Published in J. Environ. Qual. 31:1858-1867 (2002). ing the USEPA and Canadian health standards limit of $10 \mathrm{mg} \mathrm{NO}-\mathrm{N} \mathrm{L}_{3}^{-1}$ for drinking water (Health Canada, 1996; Randall et al., 1997; Thompson et al., 2000; Weil et al., 1990). In the province of Quebec, Canada, Madramootoo et al. (1992) documented levels of $\mathrm{NO}_{3}^{-}$as high as $40 \mathrm{mg} \mathrm{NO} \mathrm{NO}_{3}^{-}-\mathrm{N} \mathrm{L}^{-1}$ in subsurface drain flow from a sandy loam field cropped to potato (Solanum tuberosum L.). Increasing public concern about deteriorating water quality has prompted a growing interest for the development of various preventive and remedial management strategies.

Water table management (WTM) including controlled drainage-subirrigation (SI) is one promising technique to help reduce $\mathrm{NO}_{3}^{-}$ground water pollution. Raising the water table by subirrigation increases soil saturation and restricts $\mathrm{O}_{2}$ diffusion in soil pores, thus creating reducing conditions that promote $\mathrm{NO}_{3}^{-}$losses by denitrification. Drury et al. (1997) reported that a SI system reduced $\mathrm{NO}_{3}^{-}$concentration in tile drainage water by $25 \%$ compared with a free drainage (FD) system. Similarly, Jacinthe et al. (1999) estimated a 40\% reduction in soil $\mathrm{NO}_{3}^{-}$due to denitrification in SI plots compared with FD plots. Enhanced denitrification reduces $\mathrm{NO}_{3}^{-}$ in the soil-water solution and, hence, the risk of $\mathrm{NO}_{3}^{-}$ leaching to ground water. However, a possible consequence of this practice is increased nitrous oxide $\left(\mathrm{N}_{2} \mathrm{O}\right)$ emission to the atmosphere. Nitrous oxide emissions are of serious concern as they contribute to greenhouse effects (Smith, 1990) and participate in the depletion of the ozone layer (Mooney et al., 1987). Fortunately, $\mathrm{N}_{2} \mathrm{O}$ is not the only end product of denitrification as it may further be reduced to $\mathrm{N}_{2}$, which is harmlessly carried into the atmosphere. We are currently conducting field trials to elucidate effects of water table depth on the $\mathrm{N}_{2} \mathrm{O}$ to $\mathrm{N}_{2}$ ratio.

Water table management may also benefit crop yield. The water table elevated by SI provides abundant moisture and helps satisfy plant evapotranspiration requirements. Optimum water table depth (WTD) is a function of crop and soil type. Kalita and Kanwar (1993) have shown that the highest yield of corn grown on sandy loam soils was obtained with a WTD of 0.6 to $0.9 \mathrm{~m}$, and the lowest with a WTD of 0.2 to $0.3 \mathrm{~m}$. Similarly, Tan et al. (1996) reported optimal corn yield at a WTD of $0.6 \mathrm{~m}$, but a $15 \%$ yield reduction at a WTD of $0.3 \mathrm{~m}$. These findings agree with those of Wesseling (1974), who found that a too-shallow WTD reduces oxygen supply to roots, reduces nutrient uptake and crop growth, and restricts rooting volume.

The integration of water table management into a $\mathrm{N}$ fertilization strategy could further mitigate environmen-

Abbreviations: FD, free drainage; SI, subirrigation; WTD, water table depth; WTM, water table management. 
tal degradation while optimizing crop yield. Knowledge of interactions between WTM and N fertilization is required to development best management practices. The objectives of this study were to (i) assess water table management effectiveness in removing $\mathrm{NO}_{3}^{-}-\mathrm{N}$ from the soil-water system, (ii) investigate the combined effects of water table depth and $\mathrm{N}$ fertilization rate on denitrification rate, and (iii) elucidate the effects of SI and $\mathrm{N}$ rates on corn yield.

\section{MATERIALS AND METHODS}

\section{Field Management}

The 4.2-ha research site was a privately owned field located at St-Emmanuel near Côteau-du-Lac, Quebec $\left(74^{\circ} 11^{\prime} 15^{\prime \prime} \mathrm{N}\right.$, $45^{\circ} 2^{\prime} 10^{\prime \prime} \mathrm{W}$ ). The soil was of sedimentary origin. It was a Soulanges fine sandy loam (fine silty, mixed, non-acid Frigid Humaquept, Gleysol, according to the FAO classification system). The site was under pasture before 1991 and under continuous corn production thereafter. Surface topography was generally flat with an average slope of less than $0.5 \%$. A clay layer at about a $0.5-\mathrm{m}$ depth impeded natural drainage. The field was planted with corn (Pioneer [Des Moines, IA] Hybrid 3905 ) at a density of 75000 plants ha ${ }^{-1}$ with 0.75 - and $0.15-\mathrm{m}$ inter- and intra-row spacings, on 17 May 1996, 23 May 1997, and 8 May 1998. Potassium (muriate of potash, 0-0-60 N-P-K) was broadcast at a rate of $90 \mathrm{~kg} \mathrm{~K}_{2} \mathrm{O}$ ha $^{-1}$ roughly one week before planting. In addition, the farmer applied manure (cattle slurry) to the field in spring 1998 at a rate of $20 \mathrm{Mg} \mathrm{ha}^{-1}$ (wet weight). To control weeds, $1.5 \mathrm{~kg}$ a.i. ha ${ }^{-1}$ atrazine [6-chloro$N$ ethyl- $N$ (1-methylethyl)-1,3,5-traizine-2,4-diamine], $0.32 \mathrm{~kg}$ a.i. ha ${ }^{-1}$ dicamba (3,6-dichloro-2methoxybenzoic acid), 0.32 $\mathrm{kg}$ a.i. ha ${ }^{-1}$ bromoxynil (3,5-dibromo4-4hydroxybenzonitrile), and $1.92 \mathrm{~kg}$ a.i. ha ${ }^{-1}$ metolachlor [2-chloro- $N$-(2-ethyl-6-methylphenyl)- $N$-(2-methoxy-1-methylethyl) acetamide] were applied to the field on 23 May 1996, 25 June 1997, and 13 May 1998. All field operations other than seeding, fertilizer treatment, and herbicide applications were performed by the farmer as part of his normal production practices. Experimen- tal plots were under a conventional tillage system (i.e., moldboard-plowed to $0.20 \mathrm{~m}$ in fall and disked in spring, the common practice in the region).

\section{Experimental Design}

Schematic representation of the field layout is depicted in Fig. 1. Briefly, treatments consisted of a factorial combination of two water table management treatments (FD with open drains $1 \mathrm{~m}$ in depth from the soil surface and SI with a design water table $0.6 \mathrm{~m}$ below the soil surface) and two fertilizer rates (120 kg N ha ${ }^{-1}\left[\mathrm{~N}_{120}\right]$ and $\left.200 \mathrm{~kg} \mathrm{~N} \mathrm{ha}^{-1}\left[\mathrm{~N}_{200}\right]\right)$. Diammonium phosphate (18-46-0) was banded at planting to provide approximately $24 \mathrm{~kg} \mathrm{~N} \mathrm{ha}^{-1}$ and $130 \mathrm{~kg} \mathrm{P}_{2} \mathrm{O}_{5} \mathrm{ha}^{-1}$. One month later, to reach the desired levels of $\mathrm{N}$ fertilization, 97 and $178 \mathrm{~kg}$ $\mathrm{N}$ ha ${ }^{-1}$ were surface-applied as ammonium nitrate (34-0-0) for the $\mathrm{N}_{120}$ and $\mathrm{N}_{200}$ treatments, respectively. This second application occurred on 18 June 1996, 20 June 1997, and 8 June 1998.

A factorial arrangement of treatments with water table management as main plot and $\mathrm{N}$ fertilization as subplot were laid out in a split plot design. There were three blocks, $120 \mathrm{~m}$ wide and $75 \mathrm{~m}$ long, each consisting of eight plots, $15 \mathrm{~m}$ wide and $75 \mathrm{~m}$ long. Blocks were separated by a 30 -m-wide strip of undrained land. To minimize seepage and chemical flow between plots, a plastic barrier of double thickness, 6-mil (0.6 mm) polyethylene sheeting was installed to a depth of $1.5 \mathrm{~m}$ between plots (Tait et al., 1995). However, this did not sufficiently limit lateral flow from subirrigation treatment plots to adjacent free drainage plots, resulting in below-design water table depth on subirrigation plots, and higher drain flows on free drainage plots (Kaluli, 1996). Consequently, for this study, plots adjacent to subirrigation treatment plots were placed under subirrigation and those adjacent to free drainage plots under free drainage, resulting in four of the eight plot drains per block being dedicated to the four treatment combinations, and the remaining four plot drains per block serving as buffers (Fig. 1). Each plot with a water table control at $0.6 \mathrm{~m}$ had two buffer plots on either side with the water table control also set at $0.6 \mathrm{~m}$. All buffer plots received $120 \mathrm{~kg} \mathrm{~N} \mathrm{ha}^{-1}$ (Fig. 1). In the middle of each plot, 75-mm-diameter subsurface drain
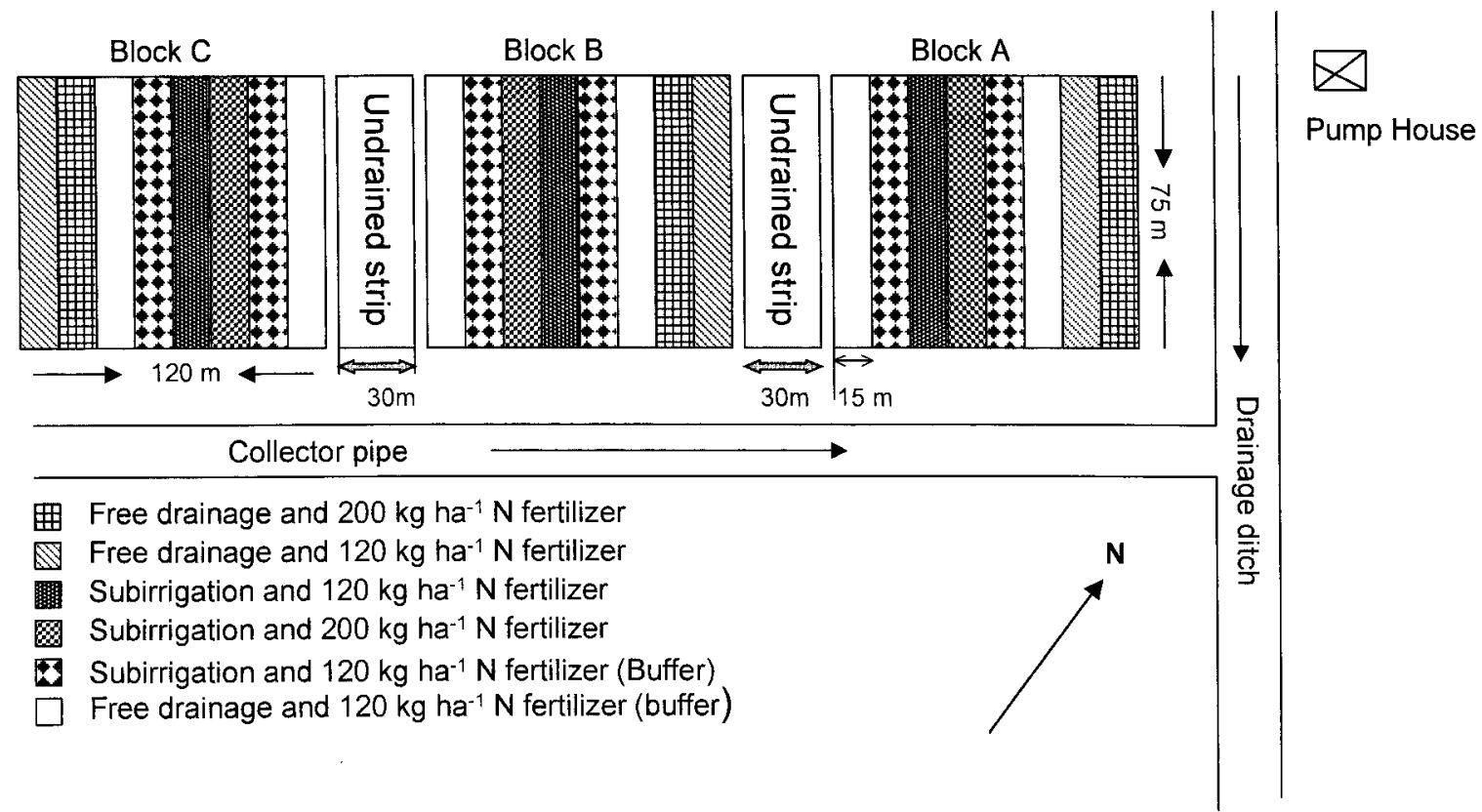

Fig. 1. Schematic representation of the experimental layout and treatment arrangements. 
pipes were installed, at a $1.0-\mathrm{m}$ depth, with a slope of $0.3 \%$. Subirrigation was imposed only after all field operations were completed and maintained until crop maturity in late September. The SI treatment was imposed immediately after planting in 1998 . Well water with no detectable nitrate was continuously pumped into the field to balance crop use and evaporative losses. Due to deep seepage it was difficult to maintain water tables at the desired depth. Following heavy rainfall events, pumping was stopped and excess water was drained to a $0.6-\mathrm{m}$ water table depth. Water depth fluctuations in all plots were monitored throughout the growing season. Three observation wells (pipes) wrapped with geotextile sleeves (Zodiac, London, ON) were installed diagonally across each of the treatment and buffer plots to a depth of approximately $1.5 \mathrm{~m}$. A graduated rod with a water sensor was used to measure water table levels. Rainfall and air temperature data were obtained from an Environment Canada weather station situated $500 \mathrm{~m}$ from the experimental site. Soil temperature was recorded at the same sampling date as for denitrification with a waterresistant probe thermometer (Hanna Instruments [Woonsocket, RI] HI9024/HI9025) inserted to $0.20 \mathrm{~m}$ below the soil surface.

\section{Sampling Strategies and Analysis}

For total denitrification measurements, soil samples (0- to 0.15-m depth) were collected weekly from late May to July and biweekly from August to October during the 1998 growing season, and approximately biweekly during the 1996 and 1997 growing seasons. In 1996, sampling started in mid-July after the drainage system was switched to SI mode. On each sampling date, aluminum cylinders $(50 \mathrm{~mm}$ in diameter $\times 150 \mathrm{~mm}$ long) were used to collect undisturbed soil cores. On each occasion, soil cores were taken on different non-wheel-tracked inter rows. The cylinders were perforated along the sides (horizontally and vertically) at $50-\mathrm{mm}$ intervals to enhance acetylene gas diffusion. Sample cylinders were placed in 2-L plastic jars fitted with rubber stoppers for gas sampling. To represent field conditions, samples were incubated outdoors overnight. Before incubation, $100 \mathrm{~mL}$ of the headspace in the jars was removed and replaced with $100 \mathrm{~mL}$ of acetylene $\left(\mathrm{C}_{2} \mathrm{H}_{2}\right)$ to give a $5 \%(\mathrm{v} / \mathrm{v})$ concentration. Acetylene was supplied to inhibit the enzymatic reduction of $\mathrm{N}_{2} \mathrm{O}$ to $\mathrm{N}_{2}$ and nitrification, so that accumulated $\mathrm{N}_{2} \mathrm{O}+\mathrm{N}_{2}$ from denitrification could be measured as $\mathrm{N}_{2} \mathrm{O}$ (Yoshinari et al., 1977).

Total $\mathrm{N}_{2} \mathrm{O}$ production was determined following the procedure of Mackenzie et al. (1997). Briefly, jar headspace gas was thoroughly mixed by inserting a syringe and pumping several times before gas sampling. About $4 \mathrm{~mL}$ of headspace gas were removed from the jars and injected into a HewlettPackard (Palo Alto, CA) 5870 Series II gas chromatograph (GC) equipped with a ${ }^{63} \mathrm{Ni}$ electron capture detector (ECD) with $\mathrm{Ar}$ and $\mathrm{CH}_{4}(95: 5)$ as a carrier gas, with oven and detector temperatures adjusted at 70 and $400^{\circ} \mathrm{C}$, respectively. Soil moisture was determined by oven-drying soil cores at $105^{\circ} \mathrm{C}$ for $48 \mathrm{~h}$ and was used to compute bulk density and water-filled pore space (WFPS).

Nitrate $\mathrm{N}$ concentration in the soil profile was assessed by collecting three sets of soil samples per plot with augers on 29 Apr. (preplanting) and 18 Oct. 1997 (postharvest) and 4 May (preplanting) and 18 Oct. 1998 (postharvest) at three depth increments $(0-0.25,0.25-0.50$, and $0.50-0.75 \mathrm{~m})$. Samples were also taken at the $0-$ to $0.2-\mathrm{m}$ depth for $\mathrm{NO}_{3}^{-}-\mathrm{N}$ analysis in conjunction with denitrification measurements. All soil samples for nitrate analysis were stored at $4^{\circ} \mathrm{C}$ for 1 to 3 wk. The samples were then thoroughly mixed and moist subsamples of $10 \mathrm{~g}$ were shaken with $100 \mathrm{~mL}$ of $1 \mathrm{M} \mathrm{KCl}$ for $60 \mathrm{~min}$. The soil suspension was filtered through Whatman (Maidstone, UK) \#5 filter papers. The filtrates were frozen before $\mathrm{NO}_{3}^{-}-\mathrm{N}$ analysis with a colorimetric autoanalyzer (Lachat [Milwaukee, WI] Quickchem).

Corn grain yield was determined by hand-harvesting individual ears from a subplot consisting of a $2.5-\mathrm{m}$ stretch of the three middle rows of each plot. Grain yield was reported on a dry-weight basis. The field was moldboard-plowed to a depth of $0.20 \mathrm{~m}$ in the first week of November, incorporating all corn stover (leaves plus stalks) into the soil.

Analysis of variance (AVOVA) was performed separately on individual sampling dates. Unless otherwise stated, the differences between treatments were declared to be significant at the 0.05 probability level. All statistical analysis were conducted with the general linear model (GLM) procedure of the Statistical Analysis System (SAS Institute, 1996).

\section{RESULTS AND DISCUSSION} Climatic Data

Total seasonal (May-October) rainfall in 1996 was $8.6 \%$ greater than the $30-y r$ normal (Table 1 ). However, the month of August was exceptionally dry, at $43 \%$ of normal, whereas July and September were both very wet, with 41 and $55 \%$ above-normal precipitation, respectively. These wetter months increased the likelihood of $\mathrm{NO}_{3}^{-}-\mathrm{N}$ leaching with the percolation water. The 1997 growing season was drier, with precipitation at $90 \%$ of normal, whereas in 1998 growing season precipitation was $29 \%$ above normal (Table 1). About $44 \%$ of the growing season precipitation in 1998 occurred in June. This overwhelmed the subirrigation system's ability to drain excess soil water, resulting in poor crop growth and yield. June 1998 was the wettest in 70 yr

Table 1. Monthly precipitation and air temperature (1996, 1997, and 1998) compared with long-term (1961-1991) normal at Côteau-duLac, Quebec.

\begin{tabular}{|c|c|c|c|c|c|c|c|c|}
\hline \multirow[b]{2}{*}{ Month } & \multicolumn{4}{|c|}{ Air temperature } & \multicolumn{4}{|c|}{ Precipitation } \\
\hline & 1996 & 1997 & 1998 & 1961-1991 & 1996 & 1997 & 1998 & 1961-1991 \\
\hline & & & & 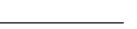 & 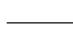 & 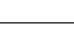 & 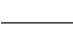 & 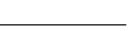 \\
\hline May & 11.7 & 10.3 & 16.5 & 12.4 & 103.8 & 64.8 & 69.6 & 76.3 \\
\hline June & 18.6 & 19.3 & 18.4 & 17.3 & 81.8 & 98.0 & 230.0 & 90.1 \\
\hline July & 19.5 & 19.5 & 20.0 & 20.2 & 133.9 & 97.0 & 128.4 & 94.6 \\
\hline August & 19.5 & 17.8 & 19.6 & 18.9 & 40.8 & 86.3 & 101.0 & 93.9 \\
\hline September & 15.7 & 14.0 & 15.1 & 14.1 & 140.6 & 81.4 & 89.4 & 90.6 \\
\hline October & 7.8 & 7.0 & 9.0 & 7.7 & 66.0 & 41.4 & 53.6 & 76.7 \\
\hline Mean & 15.5 & 14.7 & 16.4 & 15.1 & - & - & - & - \\
\hline Total & - & - & - & - & 566.9 & 468.9 & 671.6 & 522.2 \\
\hline
\end{tabular}


and the second wettest on record (National Oceanic and Atmospheric Administration, 1998). Air temperatures were 0.4 and $1.3^{\circ} \mathrm{C}$ higher than normal in 1996 and 1998, respectively, but were $0.4^{\circ} \mathrm{C}$ below normal in 1997 (Table 1); 1998 was the warmest year since 1879 (National Oceanic and Atmospheric Administration, 1998). Soil temperatures (0- to 0.2-m depth), measured in conjunction with soil sampling for denitrification, followed the same pattern as air temperature and were unaffected by either water table depth or $\mathrm{N}$ fertilization treatments (data not presented).

\section{Effects of Water Table Management on Residual Nitrate Nitrogen in the Soil Profile}

Soil $\mathrm{NO}_{3}^{-}-\mathrm{N}$ concentrations in the soil profile were generally significantly lower under SI for nearly all sampling dates and depths (Fig. 2). Exceptions were fall 1997 at the deepest sampling depth (0.5-0.75 m, Fig. 2b), spring 1998 (Fig. 2c), and fall 1998 at the uppermost depth $(0-0.25 \mathrm{~m}$, Fig. 2d) when there was no significant difference between the two water table treatments. In general, $\mathrm{NO}_{3}^{-}-\mathrm{N}$ concentrations in the soil solution decreased with depth under both SI and FD treatments. However, the decrease was sharper under the SI treatment, illustrating that $\mathrm{SI}$ affects $\mathrm{NO}_{3}^{-}-\mathrm{N}$ concentrations deeper in the soil profile and, hence, may improve ground water quality. The SI system might have created sufficiently anaerobic conditions that promoted denitri- fication and, therefore, reduced potential leaching of $\mathrm{NO}_{3}^{-}-\mathrm{N}$. Denitrification with depth has been recognized as an important mechanism for reducing $\mathrm{NO}_{3}^{-}$loading in the saturated zone (Lind and Eiland, 1989).

Measured $\mathrm{NO}_{3}^{-}-\mathrm{N}$ levels in the soil profile were higher in fall 1997 (Fig. 2b) than in fall 1998 (Fig. 2d), perhaps because relatively dry and cool conditions in 1997 (Table 1) repressed denitrification. High levels of residual soil $\mathrm{NO}_{3}^{-}-\mathrm{N}$ after harvest increase the risk of movement to surface water bodies via subsurface drains or to ground water. In spring, when evapotranspiration is low and precipitation and snow melt exceed the water holding capacity of the soil, residual $\mathrm{NO}_{3}^{-}-\mathrm{N}$ can leach beyond the crop root zone with percolating water. Patni et al. (1998) estimated that approximately $70 \%$ of $\mathrm{NO}_{3}^{-}-\mathrm{N}$ leaching occurs from fall to spring (October through April). Keeney and DeLuca (1993) found that $\mathrm{NO}_{3}^{-}-\mathrm{N}$ concentrations in the Des Moines River in Iowa, USA, were above $10 \mathrm{mg} \mathrm{L}^{-1}$ for about $14 \mathrm{~d}$ per year, mainly in the spring. It was, however, interesting to note that in the spring 1997, even though the SI system was not operational at the time of sampling, a significant reduction of $\mathrm{NO}_{3}^{-}-\mathrm{N}$ in the soil was observed (Fig. 2a). Averaged across all depths, seasonal reductions in soil $\mathrm{NO}_{3}^{-}-\mathrm{N}$ due to SI were $37 \%$ for spring $1997,2 \%$ for spring 1998, 45\% for fall 1997, and 19\% for fall 1998. Further reductions could be achieved if controlled drainage was operational during early spring or late fall, when

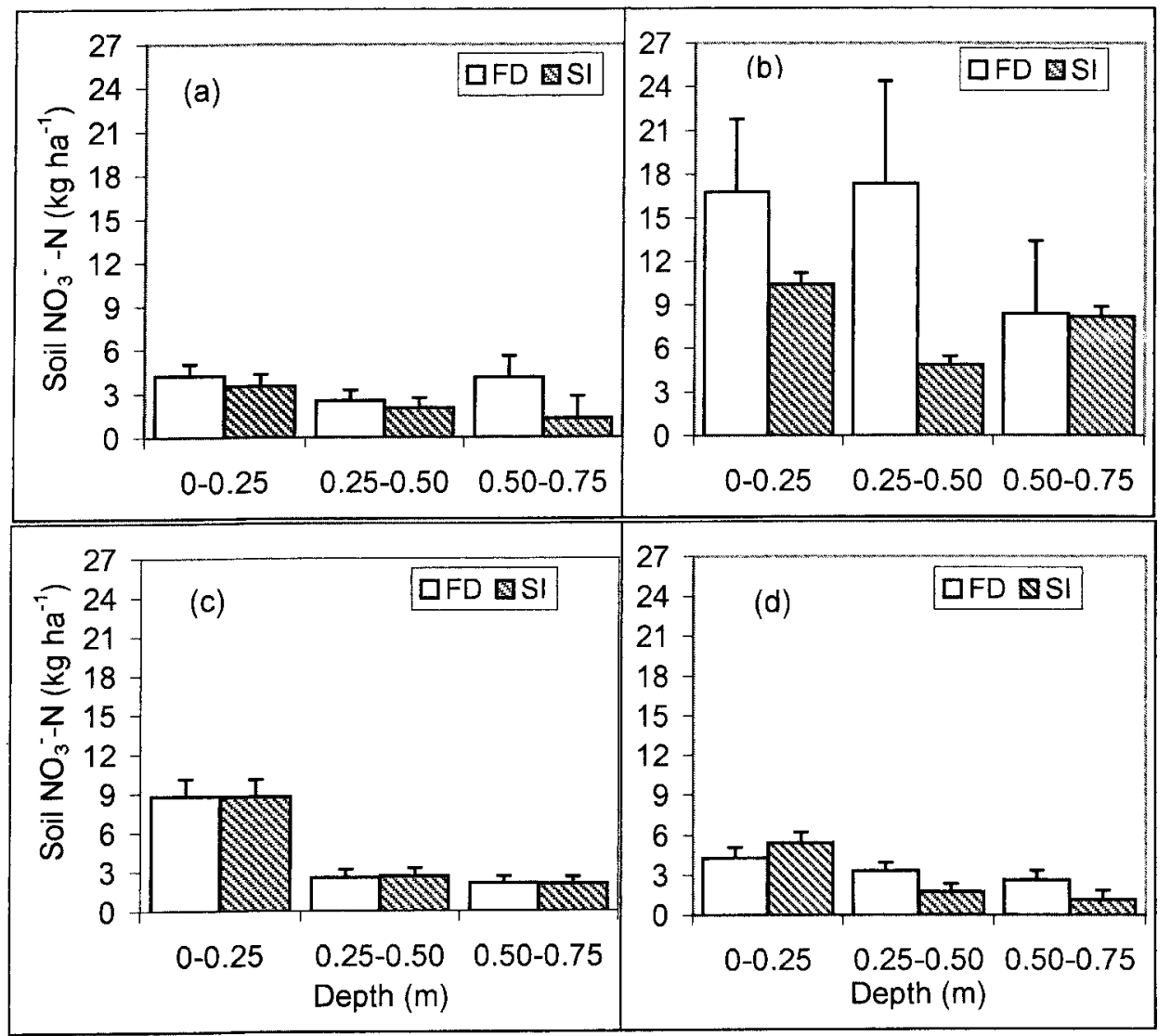

Fig. 2. Nitrate nitrogen concentrations in the soil profile under free drainage (FD) and subirrigation (SI) practices in $(a)$ spring 1997, $(b)$ fall 1997, (c) spring 1998, and $(d)$ fall 1998. Vertical bars represent standard error of the mean $(n=9)$. 
drainage is not needed to optimize crop production. If temperatures were warm enough in early spring, significantly enhanced denitrification and reduced $\mathrm{NO}_{3}^{-}-\mathrm{N}$ build up in the soil-water system could be feasible if SI did not interfere with tillage operations.

In the uppermost soil layer $(0-0.2 \mathrm{~m})$, where the effect of water table (controlled at approximately $0.6 \mathrm{~m}$ below the soil surface) was expected to be minimal, a substantial reduction of $\mathrm{NO}_{3}^{-}-\mathrm{N}$ was achieved under the SI treatment (Fig. 3). For example, although soil $\mathrm{NO}_{3}^{-}-\mathrm{N}$ values in 1996 were low, most of the sampling dates showed significantly $(P \leq 0.08$ to 0.1$)$ greater soil $\mathrm{NO}_{3}^{-}-\mathrm{N}$ under FD than SI (Fig. 3a). In 1997, while all sampling dates but the first (11 July sampling date) tended to show a greater soil $\mathrm{NO}_{3}^{-}-\mathrm{N}$ concentration under FD than SI, the difference was statistically significant only on 3 September. In 1998, $\mathrm{NO}_{3}^{-}-\mathrm{N}$ levels tended to be greater under FD than under SI, except on 23 July and 25 August, when $\mathrm{NO}_{3}^{-}-\mathrm{N}$ measured was identical under the two treatments (Fig. 3c). Statistical significance of the differences was obscured by the high variability in the data. Overall, SI management reduced surface $(0-0.0 .2 \mathrm{~m})$ soil $\mathrm{NO}_{3}^{-}-\mathrm{N}$ concentrations by $42 \%$ in $1996,16 \%$ in 1997 , and $28 \%$ in 1998 , compared with FD. The much greater $\mathrm{NO}_{3}^{-}-\mathrm{N}$ levels in 1998 (Fig. 3c) than 1996 (Fig. 3a) and 1997 (Fig. 3b) cropping seasons

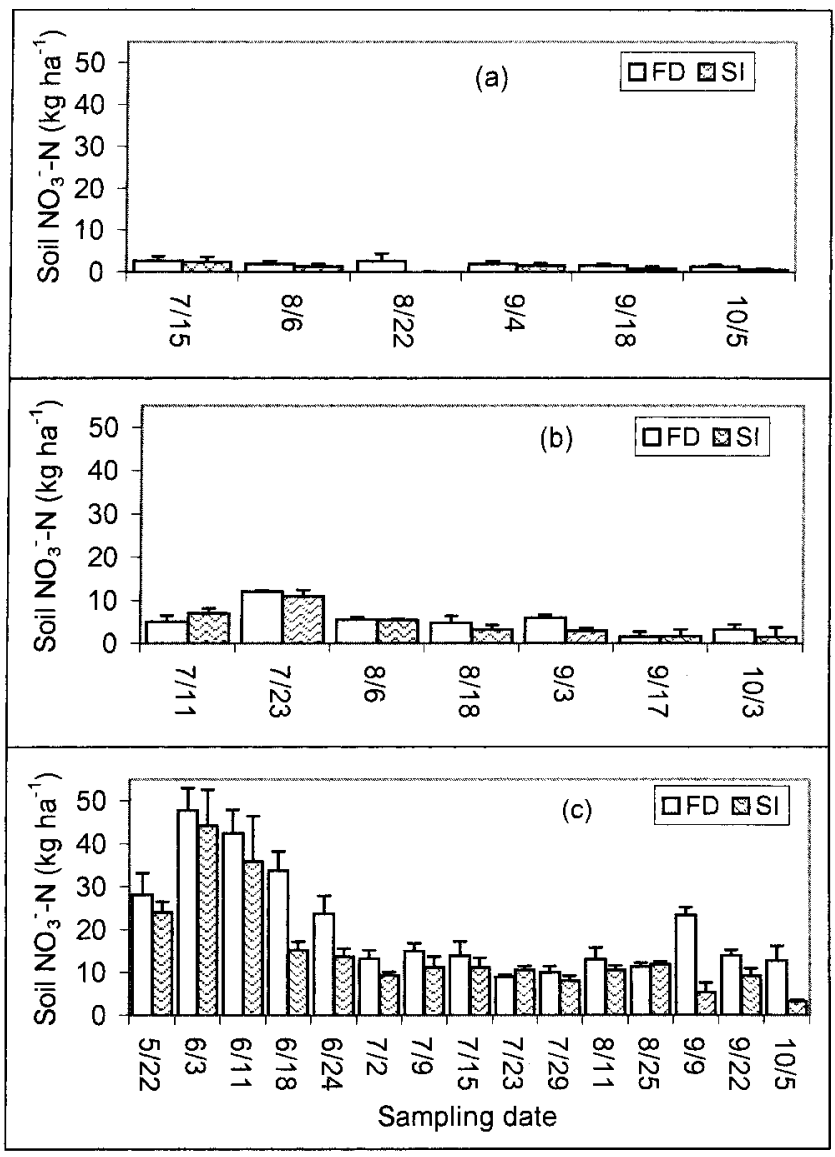

Fig. 3. Soil surface $(0-0.2 \mathrm{~m}) \mathrm{NO}_{3}^{-}-\mathrm{N}$ concentration under free drainage (FD) and subirrigation (SI) practices in (a) 1996, (b) 1997, and $(c)$ 1998. Vertical bars represent standard error of the mean $(n=3)$. may be due to the mineralization of manure applied by the farmer in the spring of 1998. Liang et al. (1995) suggested that a major portion of the manure applied in the spring was mineralized during the subsequent summer.

Water table management consists of two main alternatives: controlled drainage (CD) and subirrigation (SI). Under CD, water is prevented from exiting the soil profile by means of plugging or raising the drainage outlet. Subirrigation is similar to the CD system, except that supplemental water is pumped into the drainage system to maintain the water table at a desired level. Our findings illustrate that maintenance of a shallow water table depth can reduce $\mathrm{NO}_{3}^{-}$accumulation in the soil and limit potential pollution of ground water. Reductions in soil $\mathrm{NO}_{3}^{-}$levels of 30 to $60 \%$ have been reported for controlled drainage-subirrigation. Fogiel and Belcher (1991) found that controlled drainage-subirrigation reduced $\mathrm{NO}_{3}^{-}$loading through drainage by 25 to $59 \%$ over a 2-yr period compared with conventional drainage. Jacinthe et al. (1999) reported 24 to $43 \%$ reductions in $\mathrm{NO}_{3}^{-}$leaching with WTM techniques. Further reduction may also be possible by carefully managing fertilization rates and timing to match crop uptake.

\section{Effects of Nitrogen Rate on Nitrate Nitrogen in the Soil Profile}

The $\mathrm{NO}_{3}^{-}-\mathrm{N}$ concentrations in the soil profile under $120 \mathrm{~kg} \mathrm{~N} \mathrm{ha}^{-1}\left(\mathrm{~N}_{120}\right)$ and $200 \mathrm{~kg} \mathrm{~N} \mathrm{ha}^{-1}\left(\mathrm{~N}_{200}\right)$ treatments did not differ significantly (Fig. 4), except in spring 1998 at the surface $(0-0.25 \mathrm{~m})$ and intermediate $(0.25-0.5 \mathrm{~m})$ soil depths when $\mathrm{NO}_{3}^{-}-\mathrm{N}$ levels under $\mathrm{N}_{200}$ exceeded that under $\mathrm{N}_{120}$ (Fig. 4c). However, the clear trend for greater soil $\mathrm{NO}_{3}^{-}-\mathrm{N}$ concentrations under $\mathrm{N}_{200}$ indicates that, in the long term, even moderately high rates of $\mathrm{N}$ application may lead to accumulation of $\mathrm{NO}_{3}^{-}-\mathrm{N}$ in the soil and, consequently, $\mathrm{NO}_{3}^{-}$leaching into ground water.

Surface soil $\mathrm{NO}_{3}^{-}-\mathrm{N}$ concentrations $(0.20 \mathrm{~m})$ tended to be higher under $\mathrm{N}_{200}$ than under $\mathrm{N}_{120}$ across all seasons but differences were generally nonsignificant (Fig. 5). This suggests that limiting $\mathrm{N}$ fertilization may not be a sufficient strategy to overcome the problem of $\mathrm{NO}_{3}^{-}$ loading in the soil-water system. Sainju et al. (1998) reported that even with no fertilization, significant concentrations of residual $\mathrm{NO}_{3}^{-}-\mathrm{N}$ accumulated below the root zone because of continued mineralization from soil and crop residues.

\section{Effects of Water Table Depth and Nitrogen Rate on Denitrification}

Since there was no significant interaction between any of the treatment factors (Tables 2,3, and 4), main effects were examined independently. With the exception of a few sampling dates when WTD had dropped significantly below $0.6 \mathrm{~m}$ due to drought, denitrification rates were always higher under SI than under FD (Tables 2, 3 , and 4). Water table level fluctuated throughout the cropping seasons, responding primarily to rainfall events. Overall, average WTDs in SI plots were deeper in the drier season of 1997 (approximately $0.80 \mathrm{~m}$ ) than wetter 


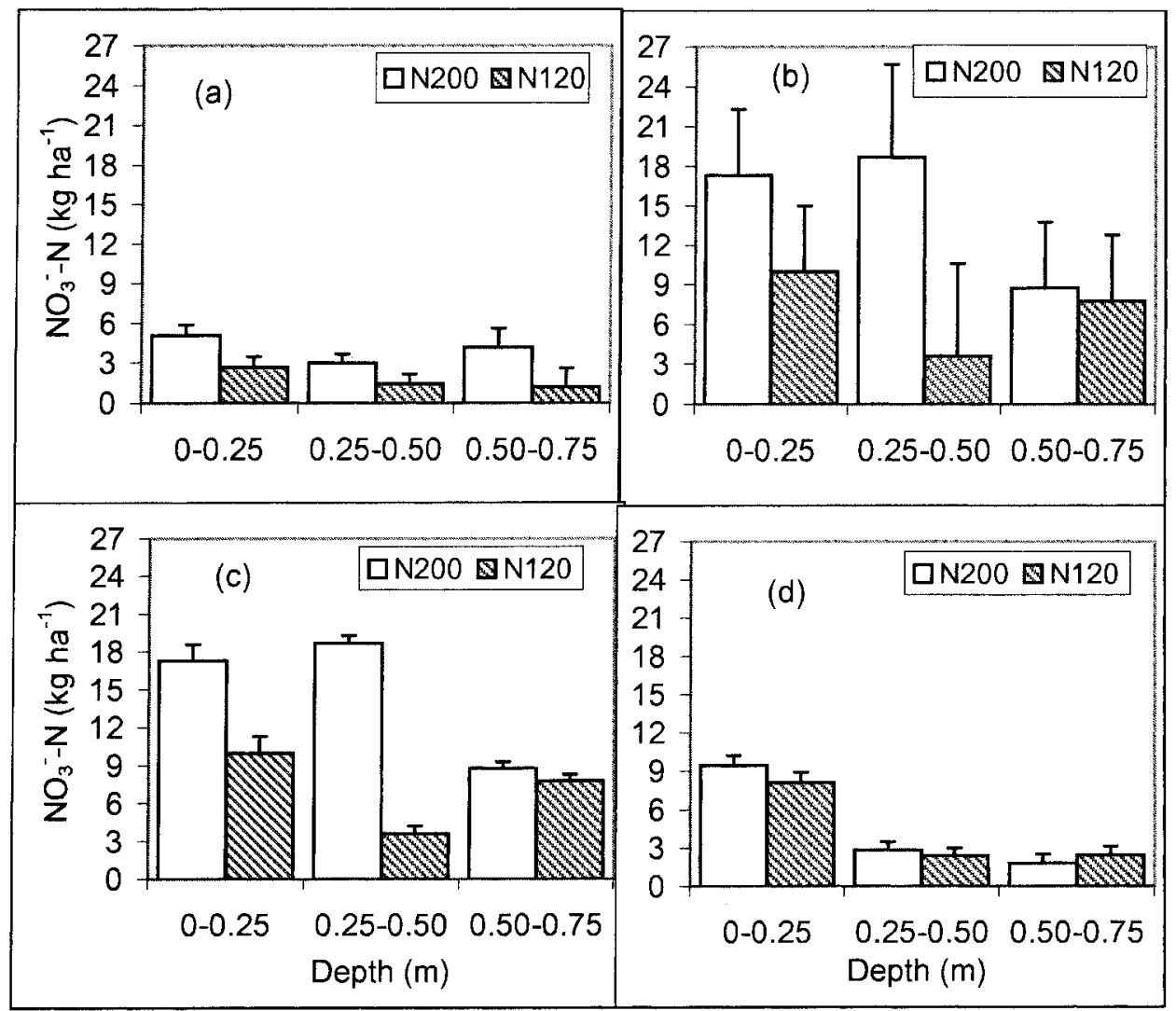

Fig. 4. Nitrate nitrogen concentrations in the soil profile under $120 \mathrm{~kg} \mathrm{~N} \mathrm{ha}^{-1}\left(\mathbf{N}_{120}\right)$ and $200 \mathrm{~kg} \mathrm{~N} \mathrm{ha}^{-1}\left(\mathbf{N}_{200}\right)(a)$ spring 1997, (b) fall 1997, (c) spring 1998, and $(d)$ fall 1998. Vertical bars represent standard error of the mean $(n=9)$.

seasons of 1996 (approximately $0.70 \mathrm{~m}$ ) and 1998 (approximately $0.65 \mathrm{~m})$. Higher denitrification losses were probably associated with the higher soil water content in SI plots compared with FD plots (Fig. 6), which decreased aeration and created conditions conducive to denitrification. Total denitrification in the 1997 season was very low. The drier conditions in 1997 (Table 1) led to a sharp drop in water table depth; $0.80 \mathrm{~m}$ from the soil surface based on seasonal average. Under such conditions, denitrification may be limited, leading to an accumulation of $\mathrm{NO}_{3}^{-}-\mathrm{N}$ in the soil profile after harvest. This is consistent with the high levels of residual soil $\mathrm{NO}_{3}^{-}-\mathrm{N}$ measured in the fall of 1997 (Fig. 2 and 3). The 1997 growing season was also cooler than normal (Table 1). Bergstrom and Beauchamp (1993), Sommerfield et al. (1993), Maag and Vinther (1999), and Fan et al. (1997) have shown that biological $\mathrm{N}_{2} \mathrm{O}$ production is enhanced at higher temperatures, especially after $\mathrm{N}$ fertilization, and lower temperatures can result in a reduction in the denitrification rate.

Averaged across all treatments, denitrification rate during the 1998 season was about 25 times greater than 1996 and 29 times greater than 1997 (Tables 2-4), and only small amounts of $\mathrm{NO}_{3}^{-}-\mathrm{N}$ were left in the soil profile after harvest. The large increase in denitrification may be due to application of manure in spring 1998 . Beauchamp et al. (1996) showed that total denitrification losses were significantly greater with liquid cattle manure than either mineral $\mathrm{N}$ or solid beef-cattle ma- nure. Manure application not only enhances the $\mathrm{N}$ supply, but also provides a source of carbon to the denitrifying community. Since denitrification measurements in 1996 started in mid-July, it is possible that the denitrification peak was missed and, therefore, caution should be used when comparing seasons.

The decrease in soil $\mathrm{NO}_{3}^{-}-\mathrm{N}$ concentration associated with SI was due to enhanced denitrification. This has created a concern that benefits from reducing $\mathrm{NO}_{3}^{-}-\mathrm{N}$ by WTM techniques may be offset by an increase in atmospheric $\mathrm{N}_{2} \mathrm{O}$ pollutant, resulting in a partial tradeoff between the two environmental concerns. However, Kliewer and Gilliam (1995) concluded that water table depth had no effect on the percentage of $\mathrm{N}_{2} \mathrm{O}$ emitted to the atmosphere via denitrification. They found that $\mathrm{N}_{2} \mathrm{O}$ emission accounted for only about $2 \%$ of the total amount of $\mathrm{N}$ denitrified. Weier et al. (1993) noted that an increase in water-filled pore space led to a strong decrease in $\mathrm{N}_{2} \mathrm{O}$ to $\mathrm{N}_{2}$ ratio. Results from our experimental plots showed that FD produced more $\mathrm{N}_{2} \mathrm{O}$ than SI (Elmi et al., 2001). These findings appear to suggest that the ecological effect of $\mathrm{N}_{2} \mathrm{O}$ produced during the denitrification process may not be as serious as was previously thought. To confirm this conclusively under natural conditions, field trials are needed to quantify the proportion of $\mathrm{N}_{2} \mathrm{O}$ to $\mathrm{N}_{2}$ ratio evolution.

Although it has been widely reported (MacKenzie et al., 1997; Henault et al., 1998; Ellis et al., 1998) that the application rate of nitrogenous fertilizers has a signifi- 


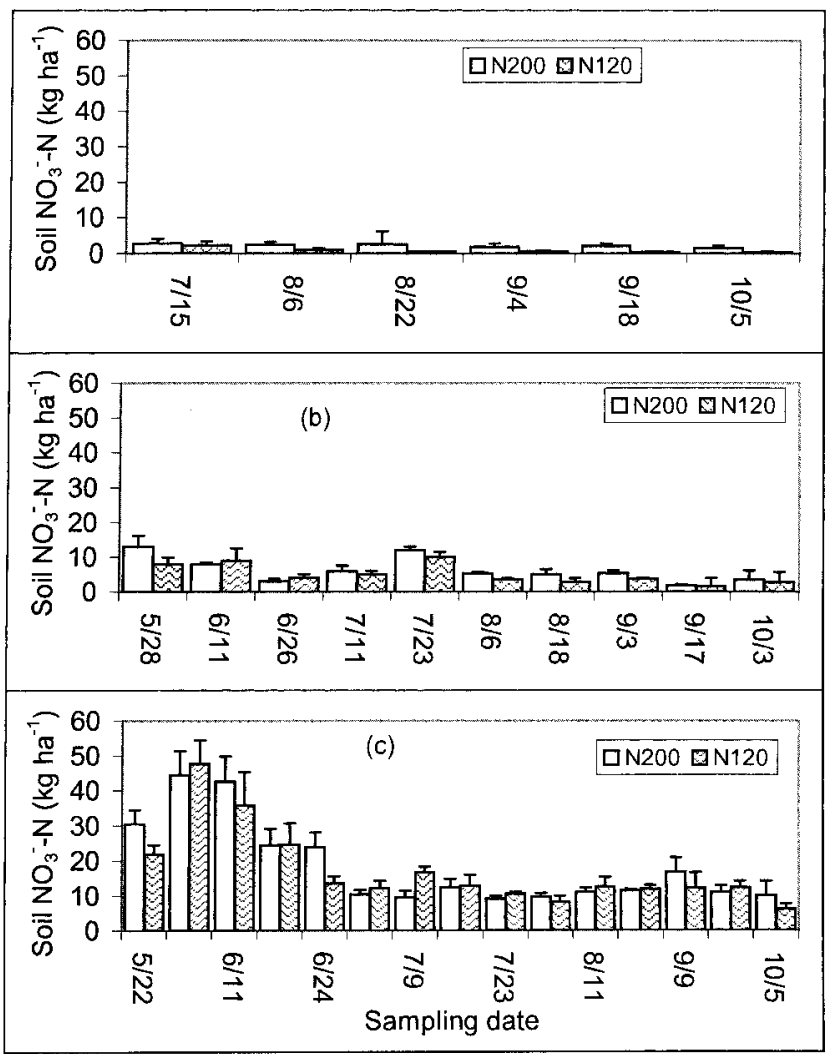

Fig. 5. Soil surface (0-0.2 m) $\mathrm{NO}_{3}^{-}-\mathrm{N}$ concentrations under $120 \mathrm{~kg} \mathrm{~N}$ $\mathrm{ha}^{-1}\left(\mathbf{N}_{120}\right)$ and $200 \mathrm{~kg} \mathrm{~N} \mathrm{ha}^{-1}\left(\mathbf{N}_{200}\right)$ rates in $(a)$ 1996, (b) 1997, and $(c) 1998$ growing seasons. Vertical bars represent standard error of the mean $(n=3)$.

cant influence on denitrification losses, we were unable to confirm this conclusion as differences between $\mathrm{N}_{120}$ and $\mathrm{N}_{200}$ treatments were seldom significant over all growing seasons (Tables 2, 3, and 4). One plausible explanation may be that soil mineral $\mathrm{N}$ content in both treatments was too high and denitrification was not limited in either one.

\section{Effects of Water Table Depth and Nitrogen Fertilization Rate on Corn Yield}

Acceptance of a new technology by farmers largely depends on its effect on crop yield. Corn yields were 7\% higher under SI than FD in 1996 and 3\% higher in 1997 (Table 5). These differences were nonsignificant. Skaggs et al. (1999) suggested that raising the water table generally increased evapotranspiration and, hence, yield. Tan et al. (1996) made similar observations and concluded that lower corn grain yields on a sandy loam soil with a water table depth of $0.8 \mathrm{~m}$ compared with $0.6 \mathrm{~m}$ were due to reduced stomatal conductance and transpiration rates caused by water stress. Doty (1980) found that the best water table depth for corn in sands or sandy loams was 0.76 to $0.89 \mathrm{~m}$.

In contrast, yields under SI were lower than under FD in 1998. Unusually heavy June rains (Table 1) overwhelmed the drainage system in the SI plots, leading to occasional ponding of water on the field. When ponding occurred, the subirrigation system had to be manually shut off for about 24 to $36 \mathrm{~h}$ to allow drainage of excess water. Corn roots, particularly when they are young, are sensitive to even short periods of restricted aeration (Evans et al., 1996). Corn stalks were visibly shorter (approximately $0.5 \mathrm{~m}$ ) under SI plots than FD plots, and yield was reduced by $25 \%$. This observation suggests that precise management of the water table is required with SI, particularly during rainy periods, and that the long-term production benefits of subirrigation depend on the system's drainage capacity. For controlled drainage-subirrigation systems to be successful, water table depth must be high enough to permit capillary rise into the root zone and low enough to ensure adequate soil aeration.

Subirrigation is expected to be more beneficial than conventional drainage during drier crop seasons as it supplements rainfall to meet crop evapotranspiration demand. Cooper et al. (1999) recorded a significant yield increase from a SI treatment in 1991, a very dry year,

Table 2. Denitrification rates as influenced by water table depth and $\mathbf{N}$ fertilization rate in 1996.

\begin{tabular}{|c|c|c|c|c|c|c|}
\hline \multirow[b]{3}{*}{ Treatments } & \multicolumn{6}{|c|}{ Denitrification rate } \\
\hline & \multicolumn{6}{|c|}{ Sampling date } \\
\hline & 15 July & 6 August & 22 August & 4 September & 22 September & 5 October \\
\hline & & & 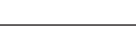 & $a^{-1} d^{-1}$ & & \\
\hline FD $\dagger$ & 185 & 32 & 27 & 6 & 14 & 5 \\
\hline SI & 225 & 113 & 22 & 31 & 26 & 15 \\
\hline $\mathbf{N}_{120} \S$ & 124 & 63 & 16 & 21 & 27 & 10 \\
\hline $\mathbf{N}_{2000}$ & 285 & 82 & 33 & 15 & 13 & 11 \\
\hline \multirow[t]{2}{*}{ Mean } & 204 & 72 & 25 & 18 & 20 & 10 \\
\hline & \multicolumn{6}{|c|}{ Summary of analysis of variance } \\
\hline WTM\# & $\mathbf{N S}+\dagger$ & ** & NS & $*$ & NS & $*$ \\
\hline N rate & $*$ & NS & NS & $* *$ & NS & NS \\
\hline $\mathbf{W T M} \times \mathbf{N}$ rate & NS & NS & NS & NS & NS & NS \\
\hline
\end{tabular}

* Significant at the 0.05 probability level.

** Significant at the 0.01 probability level.

$\dagger$ Free drainage.

$\neq$ Subirrigation.

$\$ 120 \mathrm{~kg} \mathrm{~N} \mathrm{ha}^{-1}$.

II $200 \mathrm{~kg} \mathrm{~N} \mathrm{ha}^{-1}$.

\# Water table management.

$\dagger$ Not significant. 
Table 3. Denitrification rates as influenced by water table management and $\mathbf{N}$ fertilization rate in 1997.

\begin{tabular}{|c|c|c|c|c|c|c|c|c|c|c|}
\hline \multirow[b]{3}{*}{ Treatment } & \multicolumn{10}{|c|}{ Denitrification rate } \\
\hline & \multicolumn{10}{|c|}{ Sampling date } \\
\hline & 28 May & 11 June & 26 June & 11 July & 23 July & 6 August & 18 August & 3 September & 17 September & 3 October \\
\hline & & & & & 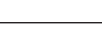 & g N ha ${ }^{-1}$ & 1 & & & \\
\hline FD $\dagger$ & 24 & 143 & 87 & 36 & 7 & 7 & 1 & 5 & 8 & 5 \\
\hline SI & 480 & 195 & 151 & 38 & 14 & 7 & 9 & 12 & 20 & 11 \\
\hline $\mathbf{N}_{120} \S$ & 37 & 150 & 143 & 35 & 12 & 9 & 7 & 11 & 18 & 10 \\
\hline $\mathbf{N}_{2000} \mid$ & 25 & 64 & 140 & 40 & 9 & 5 & 3 & 6 & 11 & 6 \\
\hline \multirow[t]{2}{*}{ Mean } & 33 & 138 & 130 & 37 & 10 & 7 & 5 & 8 & 14 & 8 \\
\hline & \multicolumn{10}{|c|}{ Summary of analysis of variance } \\
\hline WTM\# & $\mathbf{N S}+\dagger$ & NS & $*$ & NS & $*$ & NS & $* *$ & $* *$ & *** & $*$ \\
\hline $\mathbf{N}$ rate & NS & $*$ & NS & NS & NS & NS & NS & NS & NS & NS \\
\hline $\mathbf{W T M} \times \mathbf{N}$ rate & $\mathbf{N A}+\%$ & NA & NA & NS & NS & NS & NS & NS & NS & NS \\
\hline
\end{tabular}

* Significant at the 0.05 probability level.

*** Significant at the 0.01 probability level.

$\dagger$ Free drainage.

† Subirrigation.

$\$ 120 \mathrm{~kg} \mathrm{~N} \mathrm{ha}^{-1}$.

II $200 \mathbf{k g ~ N ~ h a}^{-1}$

\# Water table management.

$\dagger$ Not significant.

t+ Not applicable.

whereas the more favorable growing conditions of 1992 resulted in conventional drainage yields not differing from those obtained under SI. These results suggest that in favorable growing years there is no significant yield advantage for SI systems.

Corn yield was not affected by $\mathrm{N}$ rate in 1998 . This is an indication that $120 \mathrm{~kg} \mathrm{~N} \mathrm{ha}^{-1}$ was sufficient to maximize crop yield with WTM and favorable climatic conditions. The higher rates of $\mathrm{N}$ application $(200 \mathrm{~kg} \mathrm{~N}$ $\mathrm{ha}^{-1}$ ) produced significantly higher yields than the lower $\left(120 \mathrm{~kg} \mathrm{~N} \mathrm{ha}^{-1}\right)$ rate in 1996 and 1997, but not without potential environmental cost, as $\mathrm{NO}_{3}^{-}-\mathrm{N}$ in the soilwater system was increased.

\section{SUMMARY AND CONCLUSIONS}

Integrating water table management and $\mathrm{N}$ input strategies can minimize the risk of $\mathrm{NO}_{3}^{-}$contamination of water resources without compromising crop yields.
Similar yields were obtained with SI and FD in 1996 and 1997. Yield reduction (25\%) under SI in 1998 was attributed to the insufficient capacity of the controlled drainage-subirrigation system used to drain unusually abundant rainfall. This, however, should not adversely affect farmer's acceptance of SI, as this situation could have been averted with more rigorous management such as automating the system. Averaged across all soil depths, reduction in total soil $\mathrm{NO}_{3}^{-}-\mathrm{N}$ under SI was $37 \%$ in the spring of $1997,2 \%$ in the spring of $1998,45 \%$ in the fall of 1997, and 19\% in the fall of 1998. The adoption of WTM practices may provide an economical means to offer water quality benefits by enhancing $\mathrm{NO}_{3}^{-}$removal from the soil-water system through denitrification. Concentrations of soil $\mathrm{NO}_{3}^{-}$were greater in plots receiving a high rate of $\mathrm{N}$ fertilizer. Denitrification was higher in SI plots than FD plots, but it was seldom significantly influenced by $\mathrm{N}$ application rate.

Table 4. Dentrification rates as influenced by water table management and $\mathrm{N}$ fertilization rate in 1998.

\begin{tabular}{|c|c|c|c|c|c|c|c|c|c|c|c|c|c|c|c|}
\hline \multirow[b]{3}{*}{ Treatment } & \multicolumn{15}{|c|}{ Dentrification rate } \\
\hline & \multicolumn{15}{|c|}{ Sampling date } \\
\hline & $\begin{array}{c}22 \\
\text { May }\end{array}$ & $\begin{array}{c}3 \\
\text { June }\end{array}$ & $\begin{array}{c}11 \\
\text { June }\end{array}$ & $\begin{array}{c}18 \\
\text { June }\end{array}$ & $\begin{array}{c}24 \\
\text { June }\end{array}$ & $\begin{array}{c}2 \\
\text { July }\end{array}$ & $\begin{array}{c}9 \\
\text { July }\end{array}$ & $\begin{array}{c}15 \\
\text { July }\end{array}$ & $\begin{array}{c}23 \\
\text { July }\end{array}$ & $\begin{array}{c}29 \\
\text { July }\end{array}$ & $\begin{array}{c}11 \\
\text { August }\end{array}$ & $\begin{array}{c}25 \\
\text { August }\end{array}$ & $\stackrel{9}{\text { September }}$ & $\begin{array}{c}22 \\
\text { September }\end{array}$ & $\begin{array}{c}5 \\
\text { October }\end{array}$ \\
\hline & \multicolumn{15}{|c|}{ g N ha $\mathbf{~ h}^{-1} \mathbf{d}^{-1}$} \\
\hline FD $\dagger$ & 29 & 96 & 200 & 2320 & 895 & 671 & 282 & 508 & 51 & 254 & 163 & 105 & 209 & 105 & 144 \\
\hline SI & 260 & 237 & 715 & 4382 & 3428 & 742 & 645 & 912 & 332 & 233 & 272 & 362 & 624 & 378 & 122 \\
\hline $\mathbf{N}_{120} \S$ & 48 & 190 & 188 & 2689 & 2183 & 492 & 468 & 722 & 173 & 260 & 213 & 309 & 511 & 243 & 127 \\
\hline $\mathbf{N}_{2000} I$ & 241 & 143 & 727 & 4013 & 2140 & 921 & 458 & 698 & 209 & 227 & 222 & 158 & 322 & 241 & 139 \\
\hline \multirow[t]{2}{*}{ Mean } & 145 & 166 & 457 & 3351 & 2162 & 707 & 463 & 710 & 191 & 244 & 217 & 233 & 416 & 242 & 133 \\
\hline & \multicolumn{15}{|c|}{ Summary of analysis of variance } \\
\hline WTM\# & $\mathbf{N S}+\phi$ & NS & $*$ & NS & $* *$ & NS & NS & $*$ & NS & NS & $*$ & $*$ & $*$ & NS & NS \\
\hline N rate & NS & NS & $*$ & NS & NS & NS & NS & NS & NS & NS & NS & NS & NS & NS & NS \\
\hline WTM $\times \mathbf{N}$ rate & NS & NS & NS & NS & NS & NS & NS & NS & NS & NS & NS & NS & NS & NS & NS \\
\hline
\end{tabular}

* Significant at the 0.05 probability level.

$* *$ Significant at the 0.01 probability level.

$\dagger$ Free drainage.

† Subirrigation.

$\$ 120 \mathrm{~kg} \mathrm{~N} \mathrm{ha}^{-1}$.

II $200 \mathbf{~ k g ~ N ~ h a}^{-1}$.

\# Water table management.

$\dagger$ Not significant. 


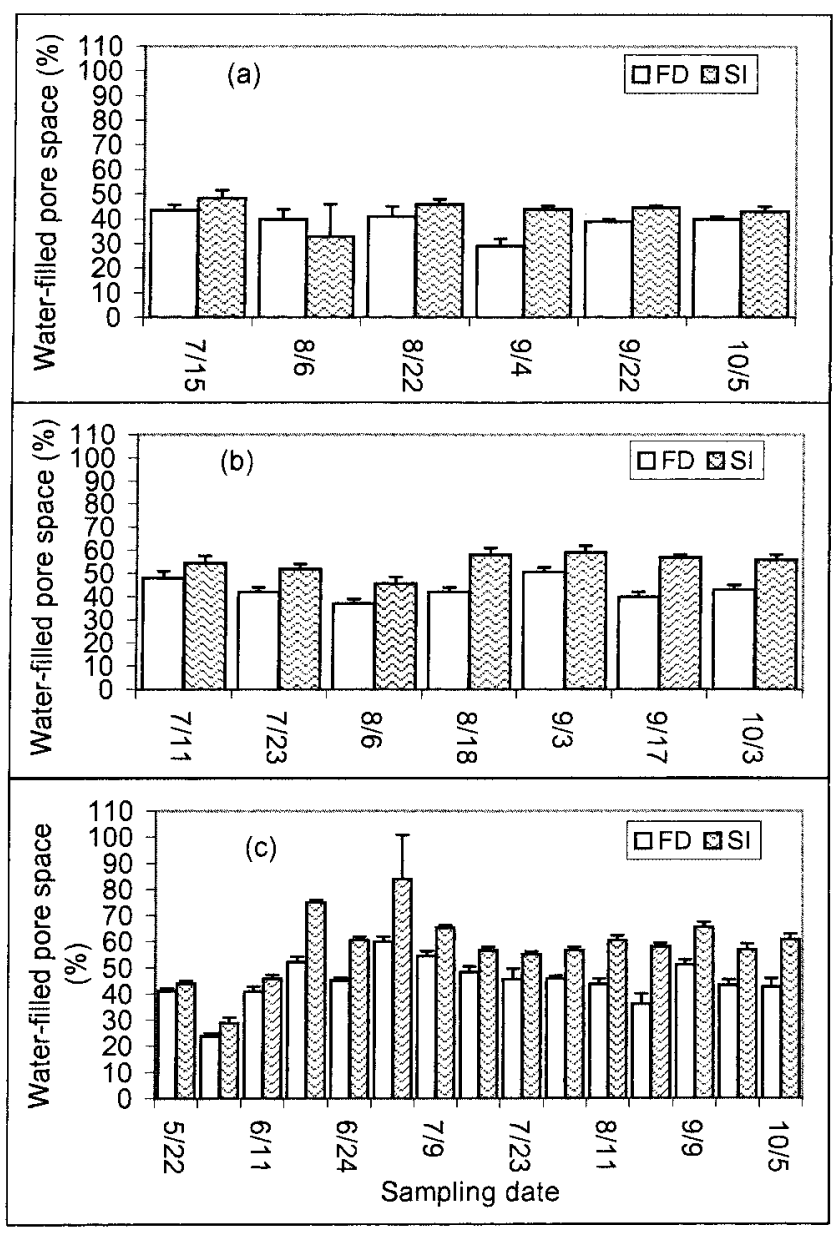

Fig. 6. Water-filled pore space (WFPS) as influenced by water table management treatments in $(a)$ 1996, (b) 1997, and (c) 1998. Vertical bars represent standard error of the mean $(n=3)$.

Our results suggest that denitrification can be an important mechanism to remove $\mathrm{NO}_{3}^{-}$from the soil-water system and, therefore, control migration and entry of $\mathrm{NO}_{3}^{-}$into surface and ground water resources. It should, however, be pointed out that the greater denitrification rate under SI may lead to an increase in $\mathrm{N}_{2} \mathrm{O}$ production. Whether $\mathrm{NO}_{3}^{-}$removal by denitrification is actually beneficial to the environment without a major tradeoff depends on which denitrification gases are produced. If a major portion of the gases produced is $\mathrm{N}_{2} \mathrm{O}$, adoption of WTM techniques could increase atmospheric $\mathrm{N}_{2} \mathrm{O}$ loading. Since $\mathrm{N}_{2} \mathrm{O}$ is detrimental to the environment, further research under field conditions is required to

Table 5. Effect of water table management and nitrogen fertilization rate on corn yield. $\dagger$

\begin{tabular}{cccccc}
\hline & \multicolumn{2}{c}{ Water table treatment } & & \multicolumn{2}{c}{ Nitrogen fertilization treatment } \\
\cline { 2 - 3 } \cline { 5 - 6 } Year & Free drainage & Subirrigation & & $120 \mathrm{~kg} \mathrm{~N} \mathrm{ha}^{-1}$ & $200 \mathrm{~kg} \mathrm{~N} \mathrm{ha}^{-1}$ \\
\cline { 2 - 3 } 1996 & $7.7(0.5)$ & $8.3(0.5)$ & & $7.1(0.45) \mathrm{b}$ & $8.7(0.13) \mathrm{a}$ \\
1997 & $8.7(0.6)$ & $9.0(0.5)$ & & $8.1(0.5) \mathrm{b}$ & $9.7(0.2) \mathrm{a}$ \\
1998 & $8.7(0.3) \mathrm{a}$ & $6.7(0.42) \mathrm{b}$ & & $7.8(0.5)$ & $7.5(0.7)$ \\
\hline
\end{tabular}

$\dagger$ Values with different letters in the same row and within water table or nitrogen treatments are statistically significantly different at $(P \leq 0.05)$ based on Fisher's $\boldsymbol{F}$ test. Values between parentheses are standard errors of the mean $(n=3)$. define the effects of water table depth on the ratio of $\mathrm{N}_{2} \mathrm{O}$ to $\mathrm{N}_{2}$ evolved through denitrification.

\section{ACKNOWLEDGMENTS}

The authors wish to thank Mr. Guy Vincent, the owner of the experimental site, for his collaboration, Dr. Georges Dodds (post-doctoral fellow, Dep. of Agricultural and Biosystems Engineering, McGill University) for his critical reading of the manuscript, and three anonymous reviewers whose comments helped improve the focus of the paper. This research was supported by a Natural Sciences and Engineering Research Council of Canada (NSERC) grant.

\section{REFERENCES}

Beauchamp, E.G., D.W. Bergstrom, and D.L. Burton. 1996. Denitrification and nitrous oxide in soil fallowed or under alfalfa or grass. Commun. Soil. Sci. Plant Anal. 27:87-99.

Bergstrom, D.W., and E.G. Beauchamp. 1993. Relationships between denitrification rate and determinant soil properties under barley. Can. J. Soil Sci. 73:567-578.

Comly, H.H. 1945. Cyanosis in infants caused by nitrates in well water. JAMA 29:112.

Cooper, R.L., N.R. Fausey, and J.W. Johnson. 1999. Yield response of corn to a subirrigation/drainage management system in northern Ohio. J. Prod. Agric. 12:74-77.

Doty, C.W. 1980. Crop water supplied by controlled and reversible drainage. Trans. ASAE 23:1122-1126.

Drury, C.F., C.S. Tan, J.D. Gaynor, T.O. Oloyo, I.J. Van Vesenbeeck, and D.J. McKenny. 1997. Optimizing corn production and reducing nitrate losses with water table control-subirrigation. Soil Sci. Soc. Am. J. 61:889-895.

Ellis, S., S. Yamulki, E. Dixon, R. Harrison, and S.C. Jarvis. 1998. Denitrification and $\mathrm{N}_{2} \mathrm{O}$ emissions from a UK pasture soil following the early spring application of cattle slurry and mineral fertiliser. Plant Soil 202:15-25.

Elmi, A.A., C. Madramootoo, and C. Hamel. 2001. Water table management as an emerging technology for bioremediation of $\mathrm{NO}_{3}^{-}-\mathrm{N}$ contaminated soils. Paper 10-112. CSAE/SCGR-NABEC, Guelph, ON, Canada.

Evans, R., W. Skaggs, and R. Sneed. 1996. Economics of controlled drainage and subirrigation systems. AG-397. North Carolina Coop. Ext. Serv., Raleigh.

Fan, M.X., A.F. MacKenzie, M. Abbott, and F. Cadrin. 1997. Denitrification estimates in monoculture and rotation corn as influenced by tillage and nitrogen fertilizer. Can. J. Soil Sci. 77:389-396.

Fogiel, A.C., and H.W. Belcher. 1991. Water quality impacts of water table management systems. ASAE Paper 91-2596. Am. Soc. Agric. Eng., St. Joseph, MI.

Gelberg, K.H., L. Church, G. Casey, M. London, and D.S. Roerig. 1999. Nitrate levels in drinking water in rural New York State. Environ. Res. Sect. A 80:34-40.

Health Canada. 1996. Guidelines for Canadian drinking water quality. 6th ed. Canada Communications, Ottawa, ON.

Henault, C., X. Davis, J.L. Lucas, and J.C. German. 1998. Influence of different agricultural practices (type of crop, form of $\mathrm{N}$ fertilizer) on soil nitrous oxide emissions. Biol. Fertil. Soils 27:299-306.

Jacinthe, P.A., W.A. Dick, and L.C. Brown. 1999. Bioremediation of nitrate-contaminated shallow soils using water table management techniques: Nitrate removal efficiency. Trans. ASAE 42:1251-1259.

Kalita, P.K., and R.S. Kanwar. 1993. Effect of water table management practices on the transport of nitrate- $\mathrm{N}$ to shallow groundwater. Trans. ASAE 36:413-421.

Kaluli, W.J. 1996. Water table management and cropping systems for intensive corn production. Ph.D. thesis. McGill Univ., Dep. Agric. Biosyst. Eng., Montreal, QC.

Keeney, D.R., and T.H. DeLuca. 1993. Des Moines river nitrate in relation to watershed agricultural practices: 1945 versus 1980s. J. Environ. Qual. 22:267-272.

Kliewer, B.A., and J.W. Gilliam. 1995. Water management effects on denitrification and nitrous oxide evolution. Soil Sci. Soc. Am. J. 59:1694-1701. 
Liang, B.C., E.G. Gregorich, and M. Schnitzer. 1995. Mineral nitrogen accumulation in soils as affected by water-soluble organic carbon extracted from composted diary manure. Commun. Soil Sci. Plant Anal. 26:2711-2723.

Lind, A.M., and F. Eiland. 1989. Microbiological characterization and nitrate reduction in subsurface soil. Biol. Fertil. Soils 8:197-203.

Maag, M., and F.P. Vinther. 1999. Effects of temperature and water on gaseous emissions from soil treated with animal slurry. Soil Sci. Soc. Am. J. 63:858-865.

MacKenzie, A.F., M.X. Fan, and F. Cardin. 1997. Nitrous oxide emissions as affected by tillage, corn-soybean-alfalfa rotations and nitrogen fertilization. Can. J. Soil Sci. 77:145-152.

Madramootoo, C.A., K.A. Wayo, and P. Enright. 1992. Nutrient losses through tile drains from potato fields. Appl. Eng. Agric. 8:639-646.

Mooney, H.A., P.M. Vitousek, and P.A. Matson. 1987. Exchange of materials between terrestrial ecosystems and the atmosphere. Science 238:926-932.

National Oceanic and Atmospheric Administration. 1998. Climate research. Monthly reports. Available online at http://lwf.ncdc.noaa. gov/oa/reports/weather-events.html (verified 8 July 2002). NOAA, Washington, DC

Patni, N.K., L. Masse, and P.Y. Jui. 1998. Groundwater quality under conventional and no-tillage: I. Nitrate, electrical conductivity, and pH. J. Environ. Qual. 27:869-877.

Prasad, R., and J.F. Power. 1995. Nitrification inhibitors for agriculture, health, and environment. Adv. Agron. 54:233-281.

Prunty, L., and B.R. Montgomery. 1991. Lysimeter study of nitrogen fertilizer and irrigation rates on quality of recharge water and corn yield. J. Environ. Qual. 20:373-380.

Randall, G.W., D.R. Huggins, M.P. Russelle, D.J. Fuchs, W.W. Nelson, and J.L. Anderson. 1997. Nitrate losses through subsurface tile drainage in conservation reserve program, alfalfa, and row crop systems. J. Environ. Qual. 26:1240-1247.
Sainju, U.M., B.P. Singh, and W.F. Whitehead. 1998. Crop root distribution and its effects on soil nitrogen cycling. Agron. J. 90:511-518.

SAS Institute. 1996. SAS user's guide. SAS Inst., Cary, NC.

Skaggs, R.W., W.R. Reynolds, and G.M. Chescheir. 1999. Effects of subsurface drain depth on nitrogen losses from drained lands. ASAE Paper 99-2086. Am. Soc. Agric. Eng., St. Joseph, MI.

Smith, K.A. 1990. Greenhouse gas fluxes between land surface and atmosphere. Prog. Phys. Geogr. 14:349-372.

Sommerfield, R.A., A.R. Mosier, and R.C. Musselman. 1993. $\mathrm{CO}_{2}$ $\mathrm{CH}_{4}$, and $\mathrm{N}_{2} \mathrm{O}$ flux through a Wyoming snowpack and implications for global budgets. Nature 361:140-142.

Tait, R., C.A. Madramootoo, and P. Enright. 1995. An instrumented, field scale research facility for drainage and water quality studies. Comput. Electron. Agric. 12:131-145.

Tan, C.S., C.F. Drury, J.D. Gaynor, I. van Wesenbeeck, and M. Soultani. 1996. Effect of water table management and nitrogen supply on yield, plant growth, and water use of corn in undisturbed soil columns. Can. J. Plant Sci. 76:229-235.

Thompson, T.L., T.A. Doerge, and R.E. Godin. 2000. Nitrogen and water interactions in subsurface drip-irrigated cauliflower: II. Agronomic, economic, and environmental outcomes. Soil Sci. Soc. Am. J. 64:412-418

Weier, K.L., J.W. Doran, J.F. Power, and D.T. Walters. 1993. Denitrification and the dinitrogen/nitrous oxide ratio as affected by soil water, available carbon, and nitrate. Soil Sci. Soc. Am. J. 57:66-72.

Weil, R.R., R.A. Weismiler, and R.S. Turner. 1990. Nitrate contamination of groundwater under irrigated Coastal Plain soils. J. Environ. Qual. 19:441-448.

Wesseling, J. 1974. Crop growth in wet soils. p. 7-37. In J. Van Schilfgaard (ed.) Drainage for agriculture. ASA, Madison, WI.

Yeomans, J.C., J.M. Bremner, and G.W. McCarty. 1992. Denitrification capacity and denitrification potential of subsurface soils. Commun. Soil Sci. Plant Anal. 23:919-927.

Yoshinari, T., R. Haynes, and R. Knowles. 1977. Acetylene inhibition of nitrous oxide reduction and measurement of denitrification and nitrogen fixation in soil. Soil Biol. Biochem. 9:177-183. 